\title{
PENERAPAN MODEL PEMBELAJARAN KOOPERATIF TIPE-STAD BERBANTUAN LKPD UNTUK MENINGKATKAN AKTIVITAS DAN HASIL BELAJAR IPA SMA
}

\author{
Sutamah \\ Universitas Tanjungpura \\ Email : Sutamah659@gmail.com
}

\begin{abstract}
Abstrak
Penelitian ini dilakukan untuk mengetahui peningkatan aktivitas dan hasil belajar peserta didik pada materi konsep reaksi reduksi-oksidasi di kelas X IPA-2 SMA Negeri 6 Pontianak melalui penerapan model pembelajaran kooperatif tipe - STAD berbantuan lembar kerja peserta didik (LKPD). Tempat pelaksanaan di SMA Negeri 6 Pontianak, Jalan Tani Tanjung Raya II Pontianak semester genap tahun ajaran 2017/2018. Subjek penelitian adalah peserta didik kelas X IPA-2 berjumlah 35 orang. Penelitian dilaksanakan dalam 2 siklus. Berdasarkan hasil analisis data, diperoleh temuan sebagai berikut : (1) Terjadi peningkatan aktivitas belajar peserta didik. Pada siklus I persentase keaktifan peserta didik adalah 55\%, pada siklus II persentase keaktifan peserta didik naik menjadi 70\%. (2) Terjadi peningkatan hasil belajar peserta didik. Pada siklus I persentase ketuntasan belajar 57\%, pada siklus II persentase ketuntasan belajar naik menjadi $77,4 \%$. Jadi, jika aktivitas belajar meningkat maka hasil belajar peserta didik akan meningkat pula.
\end{abstract}

Kata kunci : Model Kooperatif Tipe-STAD, Aktivitas, Hasil Belajar

\section{PENDAHULUAN}

Kimia merupakan salah satu mata pelajaran IPA yang paling tidak disukai oleh peserta didik, hal ini dikarenakan peserta didik beranggapan pelajaran kimia sukar dan banyak hitungan serta penyetaraan reaksi. Kesemua hal diatas membuat minat, aktivitas serta hasil belajar kimia kelas X IPA di SMA Negeri 6 Pontianak sangat rendah atau belum mencapai tingkat ketuntasan yang diharapkan.

Salah satu materi yang menjadi momok bagi peserta didik dalam pelajaran kimia adalah materi Reaksi redoks. Reaksi redoks merupakan salah satu topik penting dalam ilmu kimia. Silberberge (Osterlund, 2010 ) menyatakan bahwa reaksi redoks berperan penting dalam berbagai proses kimia seperti reaksi fotosintesis, reaksi pembakaran bahan bakar fosil dan perkaratan logam. Selain itu, aplikasi reaksi redoks seperti penggunaan baterai dan aki banyak ditemukan pemakaiannya di masyarakat luas.
Hal tersebut menunjukkan bahwa reaksi redoks dekat dengan kehidupan sehari-hari. Dengan demikian, seharusnya topik reaksi redokslebih mudah dipelajari oleh peserta didikkarena, produknya lebih dekat dengan kehidupan sehari-hari.

Namun dari hasil obeservasi dan pengalaman penulis di lapangan pada semester 2 (genap) tahun 2016 nilai rata-rata ulangan reaksi redoks kelas X IPA adalah 51,4 dengan persentase ketuntasan 45,25\% (belum mencapai KKM $=76$ berdasarkan analisis ulangan harian peserta didik tahun 2016/2017).

Model Pembelajaran Kooperatif. Pada awal abad pertama seorang filosof berpendapat bahwa untuk dapat belajar, seseorang harus memiliki pasangan atau teman. Dari situlah ide pembelajaran kooperatif itu dikembangkan. Beberapa kajian telah menemukan bahwa ketika para peserta didik bekerja bersama-sama untuk meraih sebuah tujuan kelompok, membuat 
mereka melakukan apapun yang diperlukan untuk keberhasilan kelompoknya.

Menurut R.M. Felder dan R.Brent dalam buku PAKEM (Dasim Budimansyah dkk, 2010:51) pembelajaran bersama (cooperative learning) mempunyai beberapa karakteristik yaitu (1) peserta didik bekerja dalam tim untuk mengerjakan proyek memecahkan masalah; (2) dapat dilaksanakan dalam jangka waktu yang pendek atau lama.

Tujuan pembelajaran kooperatif adalah untuk meningkatkan rasa kebersamaan dan meningkatkan kecerdasan emosional.Berdasarkan karakteristik dan tujuannya maka disimpulkan bahwa pembelajaran kooperatif adalah pembelajaran yang mengharuskan peserta didik untuk bekerja dalam satu tim untuk menyelesaikan masalah, menyelesaikan tugas, atau mengerjakan sesuatu untuk tujuan bersama. Pembelajaran kooperatif ini didasarkan pada gagasan atau pemikiran bahwa peserta didik bekerja bersama-sama dalam belajar, dan bertanggung jawab terhadap aktifitas belajar kelompok mereka seperti terhadap diri mereka sendiri. Masing-masing anggota kelompok bertanggung jawab tidak hanya pada apa yang dipelajari tetapi juga untuk membantu teman satu kelompok.

Roger dan David Johnson dalam buku Cooperative Learning (Agus Suprijono, 2013:58) mengatakan bahwa tidak semua belajar kelompok bisa dianggap pembelajaran kooperatif. Untuk mencapai hasil yang maksimal, lima unsur dalam model pembelajaran kooperatif harus diterapkan. Lima unsur tersebut adalah (a) Positive interdependence (saling ketergantungan positif); (b) Personal responsibility (tanggung jawab perseorangan); (c) Face to face promotive interaction (interaksi promotif); (d) Interpersonal skill (komunikasi antaranggota); dan (e) Group processing (pemrosesan kelompok).

Model pembelajaran kooperatif dikembangkan untuk mencapai hasil belajar berupa prestasi akademik, toleransi, menerima keragaman, dan pengembangan keterampilan sosial. Untuk mencapai hasil belajar itu model pembelajaran kooperatif menuntut kerja sama dan interdependensi peserta didik dalam struktur tugas, struktur tujuan, dan struktur reward-nya. Struktur tugas berhubungan bagaimana tugas diorganisir. Struktur tujuan dan reward, mengacu pada derajat kerja sama atau kompetisi yang dibutuhkan untuk mencapai tujuan maupun reward.

Tipe STAD (Student Team Achievement Divisions). Pembelajaran kooperatif tipe STAD (Student Team Achievement Divisions) yang dikembangkan oleh Robert Slavin dan teman-temannya di universitas John Hopkin (dalam Slavin, 1995) merupakan pembelajaran kooperatif yang paling sederhana, dan merupakan pembelajaran kooperatif yang cocok digunakan oleh guru yang baru mulai menggunakan pembelajaran kooperatif. Student Team Achievement Divisions (STAD) adalah salah satu tipe pembelajaran kooperatif yang paling sederhana .peserta didik ditempatkan dalam tim belajar beranggotakan empat orang yang merupakan campuran menurut tingkat kinerjanya, kelamin dan suku.

Guru menyajikan pelajaran, kemudian peserta didik belajar dalam tim untuk memastikan bahwa seluruh anggota dalam tim telah mengusai pelajaran tersebut. Akhirnya seluruh peserta didik dikenai kuis tentang materi tersebut dengan catatan, saat kuis mereka tidak boleh saling membantu. Tipe pembelajaran inilah yang akan diterapakan dalam pembelajaran reaksi redoks.

Aktivitas Belajar Peserta didik. Dalam proses pembelajaran yang diperhatikan pertama kali adalah peserta didik, bagaimana keadaan dan kemampuannya, baru setelah itu menentukan komponen-komponen yang lain seperti apa bahan yang diperlukan, bagaimana cara yang tepat untuk bertindak (metode), alat dan fasilitas apa yang cocok dan mendukung. Oleh karena itu, lebih tepat kalau peserta didik dikatakan sebagai subjek dalam proses pembelajaran sehingga peserta didik tersebut 
sebagai subjek belajar (Sardiman, 2008 : 112).

Menurut Paul B. Diedrich (Sardiman, 2008 : 101), ada beberapa jenis aktivitas dalam belajar antara lain (a) Visual activities, seperti membaca, memperhatikan gambar demonstrasi, percobaan, mengamati pekerjaan orang lain dan sebagainya; (b) Oral activities, seperti menyatakan, merumuskan, bertanya, memberi saran, mengeluarkan pendapat, mengadakan wawancara, diskusi, interupsi, dan sebagainya; (c) Listening activities, seperti mendengarkan uraian, percakapan, diskusi musik, pidato, dan sebagainya; (d) Writing activities, seperti menulis cerita, karangan, laporan, tes, angket, menyalin, dan sebagainya; (e) Drawing activities, seperti menggambar, membuat grafik, peta dan diagram; (f) Motor activities, seperti melakukan percobaan, membuat konstruksi, model mereparasi, bermain, berkebun, memelihara binatang, dan sebagainya; (g) Mental activities, seperti menanggapi, mengingatkan, memecahkan soal, menganalisa, melihat hubungan dan mengambil krputusan; dan (h)Emotional activities, seperti menaruh minat, merasa bosan, gembira, berani, tenang, gugup, dan sebagainya.

Aktivitas belajar peserta didik terhadap pembelajaran kooperatif tipe STAD (Student Team Achievement Divisions) adalah keikutsertaan peserta didik secara aktif dalam pembelajaran kooperatif tipe STAD . Alat ukur aktivitas belajar peserta didik berupa lembar observasi aktivitas belajar peserta didik.

Hasil Belajar. Penilaian hasil belajar merupakan bagian yang tidak terpisahkan dengan proses pembelajaran, mengapa? Karena salah satu manfaat penilaian hasil belajar adalah untuk mengukur efektivitas proses pembelajaran itu sendiri (Dasim Budimansyah dkk, 2010 : 84). Dalam Kurikulum Tingkat Satuan Pendidikan (KTSP), penilaian hasil belajar meliputi post test, ulangan harian, ulangan akhir semester, ujian sekolah, dan ujian nasional. Jika penilaian dilakukan pada akhir proses pembelajaran maka penilaian tersebut terkait dengan penilaian hasil. Hasil belajar yang dianalisis pada penelitian ini adalah nilai post test yang dilakukan pada akhir proses pembelajaran. Alat ukur hasil belajar yang digunakan adalah soal post test berbentuk pilihan ganda dan uraian.

\section{METODE PENELITIAN}

\section{Subjek, Tempat, Waktu Penelitian, Pihak} yang Membantu

\section{Subjek Penelitian}

Subjek penelitian ini adalah kelas X IPA 2 yang berjumlah 35 orang, terdiri dari 13 orang laki-laki dan 22 orang perempuan. Pemilihan kelas X IPA 2 sebagai subjek penelitian karena nilai rata-rata hasil ujian mid semester, nilai ujian semester ganjil (1) dan hasil ulangan harian tahun pelajaran 2017/2018 lebih rendah daripada kelas X IPA 1, X IPA 3, dan X IPA 4.

\section{Tempat dan Waktu Penelitian}

Penelitian ini dilaksanakan di SMA Negeri 6 Pontianak, Jalan Tanjungraya II JlnTani, Kelurahan Saigon, Kecamatan Pontianak Timur, Kota Pontianak, Provinsi Kalimantan Barat.

Penelitian Perbaikan Pembelajaran ini dilaksanakan sebanyak 2 siklus, selama 3 bulan dari Maret s.d Mei 2018. Untuk lebih jelas dapat dilihat tabel berikut ini :

Desain Prosedur Perbaikan Pembalajaran Penelitian Perbaikan Pembelajaran terdiri dari 2 siklus dengan alur kegiatan seperti gambar berikut ini. 


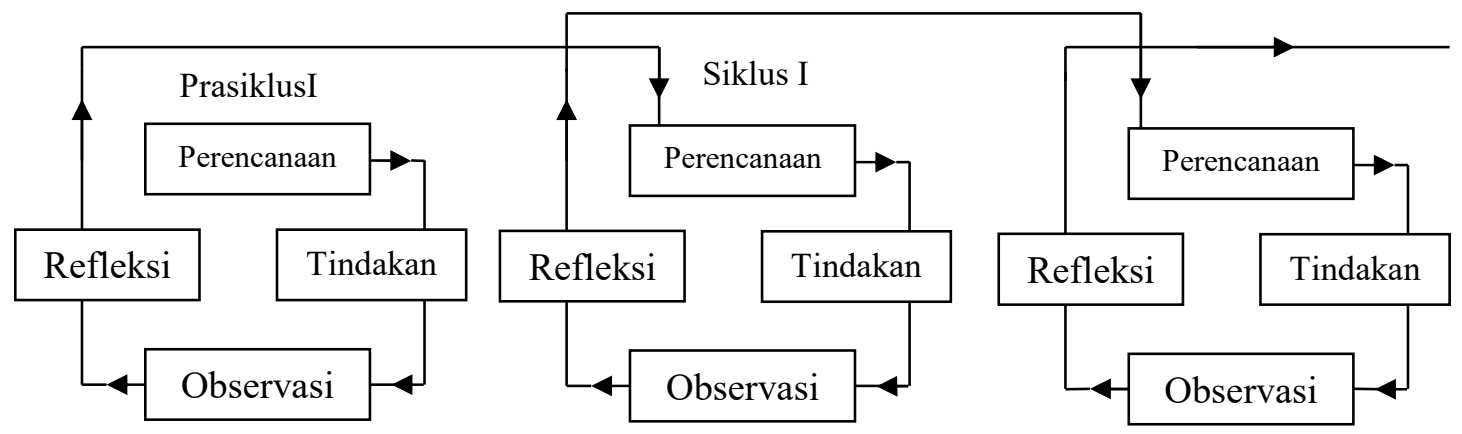

Gambar 1. Kajian Berdaur 4 tahap Penelitian Tindakan Kelas (PTK)

Data dan Teknik Pengumpulan Data

a. Data

Data yang digunakan dalam penelitian ini ada dua macam yaitu data kualitatif yang meliputi seluruh aspek yang berkaitan dengan proses penerapan model pembelajaran STAD dalam meningkatkan aktivitas dan hasil belajar Kimia konsep Reaksi Redoks pada peserta didik kelas XIPA 2 SMA Negeri 6 Pontianak tahun 2017/2018. Data-data ini mencakup perencanaan penelitian, data pada saat tindakan penelitian, serta data refleksi dan evaluasi.

Data kedua adalah kuantitatif, yaitu data yang berkaitan peningkatan aktivitas dan hasil belajar Kimia konsep Reaksi Redoks pada peserta didik kelas XIPA 2 SMA Negeri 6 Pontianak tahun 2017/2018. Hal ini dapat kita lihat pada nilai pretes, nilai akhir siklus pertama dan nilai akhir siklus kedua.

b. Teknik Pengumpulan Data

Pengumpulan data dilakukan melalui tiga cara, yaitu :

1) $\mathrm{Tes}$

Tes dilakukan untuk mengumpulkan informasi pemahaman peserta didik tentang materi yang diajarkan dengan menerapkan model pembelajaran kooperatif tipe STAD. Tes terdiri dari tes awal dan tes akhir.

2) Observasi

Observasi dilakukan selama kegiatan pembelajaran berlangsung. Pelaksanaannya dilakukan dengan mengisi format yang telah disiapkan oleh peneliti dengan tujuan untuk mengetahui aktifitas dan perilaku subyek peneliti pada saat pembelajaran berlangsung.

\section{HASIL DAN PEMBAHASAN \\ Deskripsi Hasil Penelitian Perbaikan Pembelajaran}

Penelitian perbaikan pembelajaran ini berjalan dalam dua siklus, dalam setiap siklusnya berlangsung dalam pembelajaran 2 kali tatap muka (setiap pertemuan berlangsung selama $3 \times 45$ menit). Data yang dikumpulkan dalam setiap siklus adalah data yang berhubungan dengan aktivitas belajar dan hasil belajar peserta didik melalui instrumen pengumpul data yang telah ditetapkan, dalam hal ini adalah penilaian aktivitas dan hasil belajar peserta didik dengan penerapan Model Pembelajaran kooperatif tipe STAD dalam pembelajaran Kimia yang telah disiapkan oleh penulis dalam penelitian perbaikan pembelajaran ini.

Subjek penelitian perbaikan pembelajaran ini adalah peserta didik kelas $\mathrm{X}$ IPA 2 SMA Negeri 6 Pontianak tahun pelajaran 2017 - 2018 yang berjumlah 35 orang dengan 13 orang laki-laki dan 22 orang perempuan.

Adapun hasil yang diperoleh dari pelaksanaan penelitian perbaikan pembelajaran ini dapat dijelaskan sebagai berikut.

\section{Siklus I}

Materi yang dipelajari pada siklus I adalah konsep reaksi reduksi oksidasi dengan alokasi waktu 3 x 45 menit.

\section{1) Perencanaan}

Pada tahap perencanaan dirancang perangkat dan instrumen pembelajaran 
(rencana pelaksanaan pembelajaran, lembar observasi, lembar kerja peserta didik, soal diskusi dan post test) yang digunakan dalam pelaksanaan penelitian perbaikan pembelajaran ini.

2) Pelaksanaan

Tindakan I dilaksanakan sebanyak 2 kali pertemuan yaitu pada hari jumat, 16 Maret 2018 dari jam $09.30-10.15$ dan hari Rabu, 21 Maret 2018 dari jam $08.30-10.15$, dengan menerapkan model pembelajaran kooperatif tipe Student Team Achievement Division.

3) Observasi

Pelaksanaan observasi dilakukan bersamaan dengan pelaksanaan perbaikan pembelajaran pada hari Jumat, 16 Maret 2018 dan hari Rabu, 21 Maret 2018. Observasi dilakukan dengan cara merekam segala kejadian selama pembelajaran menggunakan pedoman observasi aktivitas belajar dan penilaian proses pembelajaran yang telah disiapkan, dengan hasil sebagai berikut :

- Aktivitas Belajar

Obeservasi aktivitas belajar peserta didik dilakukan berdasarkan lembar obeservasi yang telah ditetapkan dalam perencanaan awal, dengan aspek-aspek aktivitas belajar yang diamati terdiri dari :

1) Mendengarkan dan memperhatikan penjelasan guru

2) Mengajukan pertanyaan kepada guru dan peserta didik lainnya

3) Menjawab pertanyaan guru dan peserta didik lainnya

4) Bekerja sama dalam diskusi kelompok

5) Kemampuan peserta didik dalam menyimpulkan hasil diskusi kelompok

Dari hasil observasi yang dilakukan selama pelaksanaan perbaikan pembelajaran di siklus I diproleh hasil yang dapat dilihat pada tabel berikut ini

Tabel 1. Persentase Aktivitas Belajar Peserta Didik di Kelas X IPA 2 Siklus I

\begin{tabular}{ccccc}
\hline No & Kategori & Rentang Nilai & Frekuensi & Persentase (\%) \\
\hline 1 & Baik & $\geq 70 \%$ & 8 & $23 \%$ \\
\hline 2 & Sedang & $\mathbf{3 6 \% - 6 9 \%}$ & 15 & $43 \%$ \\
\hline 3 & Kurang & $\mathbf{0 \% - 3 5 \%}$ & 12 & $34 \%$ \\
\hline Jumlah & & 35 & $100 \%$ \\
\hline
\end{tabular}

Berdasarkan data observasi di atas dapat disimpulkan bahwa aktivitas belajar kimia konsep reaksi redoks dengan menerapkan model pembelajaran kooperatif tipe STAD berbantuan LKPD masih tergolong rendah yaitu untuk kategori baik sekitar 23\%, kategori sedang sekitar $43 \%$ dan kategori kurang sekitar 34\%. Hal ini disebabkan karena peserta didik belum dapat memahami pembalajaran dengan menggunakan model pembelajaran kooperatif tipe STAD berbantuan LKPD dan guru belum dapat memotivasi peserta didik secara maksimal dalam penerapan model pembelajaran kooperatif tipe STAD berbantuan LKPD.

\section{Hasil Belajar}

Hasil belajar peserta didik di siklus I dapat dilihat dari hasil evaluasi belajar peserta didik dalam mempelajari konsep reaksi redoks dapat dilihat pada tabel berikut ini"

Tabel 2. Persentase Ketuntasan Klasikal dan Nilai Rata-Rata Nilai Untuk Konsep Reaksi Redoks Pada Siklus I

\begin{tabular}{ccccc}
\hline No & Kategori & Rentang Nilai & Frekuensi & Persentase (\%) \\
\hline 1 & Tuntas & $75-100$ & 15 & 43 \\
\hline 2 & Tidak Tuntas & $0-74$ & 20 & 57 \\
\hline Jumlah & & 35 & 100 \\
\hline
\end{tabular}


Berdasarkan hasil evaluasi belajar peserta didik yang telah dilakukan di siklus I menunjukkan hasil belajar peserta didik seperti tertera di tabel 4.2, dapat dikatakan bahwa hasil belajar peserta didik belum sesuai dengan indikator ketercapaian hasil belajar yang telah ditetapkan sebelumnya. Hasil seperti di atas menunjukkan bahwa kemampuan guru dalam melaksanakan pembelajaran menggunakan model pembelajaran tipe STAD terhadap pembelajaran Kimia Konsep Reaksi Redoks belum memperoleh hasil yang maksimal.

\section{4) Refleksi}

Berdasarkan hasil observasi pada tindakan I maka dilakukan refleksi dengan guru observer pada siklus I walaupun hasil belajar dan proses pembelajaran telah mengalami perubahan berarti, namun masih terdapat kekurangan-kekurangan. Hasil refleksi pada siklus I dapat dilihat pada tabel berikut ini.

Tabel 3. Hasil Refleksi Siklus I

\begin{tabular}{|c|c|c|}
\hline No & rangan & Solusi \\
\hline 1 & $\begin{array}{l}\text { Pada kegiatan awal guru terlalu lama } \\
\text { menjelaskan kompetensi dasar, dan tujuan } \\
\text { pembelajaran. }\end{array}$ & $\begin{array}{l}\text { Pada siklus II guru cukup membaca saja } \\
\text { kompetensi dasar dan tujuan pembelajaran. }\end{array}$ \\
\hline 2 & $\begin{array}{l}\text { Guru belum dapat mengalokasikan waktu } \\
\text { presentasi sesuai RPP karena baru } \\
\text { menerapkan model pembelajaran kooperatif } \\
\text { tipe STAD. }\end{array}$ & $\begin{array}{l}\text { Pada siklus II guru harus mengalokasikan } \\
\text { waktu presentasi sesuai yang tercantum dalam } \\
\text { RPP. }\end{array}$ \\
\hline 3 & $\begin{array}{l}\text { Peserta didik masih canggung untuk } \\
\text { berinteraksi dengan peserta didik lain dalam } \\
\text { diskusi kelompok. }\end{array}$ & $\begin{array}{l}\text { Pada siklus II diharapkan guru lebih } \\
\text { memotivasi dan mendorong peserta } \\
\text { untuk dapat bekerja sama. }\end{array}$ \\
\hline 4 & $\begin{array}{l}\text { Peserta didik yang bertanya dan menjawab } \\
\text { pertanyaan saat presentasi masih kurang. }\end{array}$ & $\begin{array}{l}\text { Pada siklus II guru lebih dapat memancing } \\
\text { peserta didik untuk berani bertanya dan } \\
\text { menjawab pertanyaan. }\end{array}$ \\
\hline 5 & $\begin{array}{l}\text { Beberapa pertanyaan peserta } \\
\text { menyimpang dari materi diskusi. }\end{array}$ & $\begin{array}{l}\text { Pada siklus II guru menegaskan agar peserta } \\
\text { didik bertanya sesuai dengan materi yang } \\
\text { dibahas. }\end{array}$ \\
\hline 6 & $\begin{array}{l}\text { u lama menjawab } \\
\text { at presentasi. }\end{array}$ & $\begin{array}{l}\text { Pada siklus II diberikan batas waktu, apabila } \\
\text { waktu telah lewat maka jawaban dilemparkan } \\
\text { kepada peserta didik yang telah siap } \\
\text { menjawab. }\end{array}$ \\
\hline 7 & $\begin{array}{l}\text { Observer kesulitan mencatat identitas peserta } \\
\text { didik yang melakukan presentasi karena tidak } \\
\text { terdapat dalam lembar pengamatan aktivitas } \\
\text { belajar peserta didik. }\end{array}$ & $\begin{array}{l}\text { Pada siklus II dalam lembar pengamatan } \\
\text { aktivitas belajar peserta didik ditambah } 1 \text { baris } \\
\text { peserta didik yang mempresentasikan hasil } \\
\text { diskusi. }\end{array}$ \\
\hline & $\begin{array}{l}\text { Siklus II } \\
\text { Materi yang dipelajari pada siklus II } \\
\text { adalah jenis reaksi redoks berdasarkan } \\
\text { konsep bilangan oksidasi dengan alokasi } \\
\text { waktu } 4 \text { x } 45 \text { menit. }\end{array}$ & $\begin{array}{l}\text { 1) Perencanaan } \\
\text { Tindakan pada yang siklus II } \\
\text { dilaksanakan berdasarkan hasil } \\
\text { refleksipelaksanaan perbaikan } \\
\text { pembelajaran di siklus I yang dapat } \\
\text { dikatakan belum berhasil. Pada } \\
\text { perencanaan siklus II merupakan }\end{array}$ \\
\hline
\end{tabular}


upaya perbaikan tindakan siklus I yang belum mencapai hasil memuaskan seperti merevisi RPP dan lembar observasi aktivitas belajar peserta didik.

\section{2) Pelaksanaan}

Tindakan II dilaksanakan pada hari Jumat, 23 Maret 2018 dari jam 90.30 - 11.00 dan Rabu 28 Maret 2018 dari jam 08.30-09.15 sd 09.3010.15 , dengan menerapkan model pembelajaran kooperatif tipe Student Team Achievement Division.

\section{3) Observasi}

Pelaksanaan observasi dilakukan bersamaan dengan pelaksanaan perbaikan pembelajaran pada hari Jumat, 23 Maret 2018 dan hari Rabu, 28 Maret 2018. Observasi dilakukan dengan cara merekam segala kejadian selama pembelajaran menggunakan pedoman observasi aktivitas belajar dan penilaian proses pembelajaran yang telah disiapkan, dengan hasil sebagai berikut :

- Aktivitas Belajar

Hasil observasi aktivitas belajar pada siklus II dapat dilihat pada tabel berikut ini :

Tabel 4. Persentase Aktivitas Belajar Peserta Didik

di Kelas X IPA 2 Siklus II

\begin{tabular}{ccccc}
\hline No & Kategori & Rentang Nilai & Frekuensi & Persentase (\%) \\
\hline 1 & Baik & $\geq 70 \%$ & 22 & $63 \%$ \\
\hline 2 & Sedang & $\mathbf{3 6 \% - 6 9 \%}$ & 9 & $\mathbf{2 6 \%}$ \\
\hline 3 & Kurang & $\mathbf{0 \% - 3 5 \%}$ & 4 & $11 \%$ \\
\hline & Jumlah & & 35 & $100 \%$ \\
\hline
\end{tabular}

Berdasarkan data pengamatan di atas diketahui bahwa terjadi peningkatan aktivitas belajar peserta didik dibandingkan dengan aktivitas belajar peserta didik pada siklus I, di mana kategori baik meningkat dari $23 \%$ di siklus I menjadi $63 \%$ di siklus II .
- Hasil Belajar

Hasil belajar peserta didik di siklus II dapat dilihat dari hasil evaluasi belajar peserta didik dalam mempelajari konsep reaksi redoks dapat dilihat pada tabel berikut ini"

Tabel 5. Persentase Ketuntasan Klasikal dan Nilai Rata-Rata Nilai Untuk Konsep Reaksi Redoks Pada Siklus II

\begin{tabular}{ccccc}
\hline No & Kategori & Rentang Nilai & Frekuensi & Persentase (\%) \\
\hline 1 & Tuntas & $\mathbf{7 5 - 1 0 0}$ & 27 & 77 \\
\hline 2 & Tidak Tuntas & $0-74$ & 8 & 23 \\
\hline & Jumlah & & 35 & 100 \\
\hline
\end{tabular}

Berdasarkan data pada Tabel 5 dapat dilihat perkembangan hasil belajar yang diperoleh peserta didik setelah melakukan tindakan siklus II dibandingkan siklus I. Persentase ketuntasan naik dari $43 \%$ menjadi $77 \%$ (terjadi peningkatan sebesar $34 \%)$. 
Setelah melakukan proses belajar dengan model pembelajaran kooperatif tipe Student Team Achievement Division. siklus II terjadi peningkatan hasil belajar. Jadi dapat disimpulkan bahwa pelaksanaan tindakan pada siklus II telah mencapai indikator (indikator keberhasilan siklus II adalah 75\% dari keseluruhan peserta didik mencapai ketuntasan belajar dengan $\mathrm{KKM}=75$ ).

\section{4) Refleksi}

Berdasarkan hasil penelitian siklus II kemudian dilakukan refleksi terhadap langkah-langkah yang telah dilaksanakan.Hasil refleksi tersebut adalah pada pelaksanaan siklus II ini sudah cukup dalam meningkatkan kegiatan aktivitas belajar peserta didik dan hasil belajar peserta didik dalam pembelajaran kimia konsep reaksi redoks dengan menerapkan model pembelajaran tipe STAD berbantu LKPD sudah mencapai indikator yang telah ditentukan, sehingga penelitian perbaikan pembelajaran ini tidak dilanjutkan kesiklus berikutnya.

\section{Pembahasan}

Indikator peningkatan aktivitas belajar dapat diketahui dari semakin banyaknya jumlah peserta didik yang aktif dalam proses pembelajaran. Jika dibandingkan dengan siklus I, pada siklus II aktivitas peserta didik mengalami peningkatan yakni dari 55\% menjadi $70 \%$, Peningkatan aktivitas belajar dapat dilihat pada tabel dan grafik berikut ini.

Tabel 6. Peningkatan Aktivitas Belajar Peserta didik Setiap Siklus.

\begin{tabular}{cccc}
\hline No & Siklus & Jumlah Peserta didik & $\begin{array}{c}\text { Rata-rata Persentase Aktivitas } \\
\text { Belajar }\end{array}$ \\
\hline $\mathbf{1}$ & I & 35 & $55 \%$ \\
\hline $\mathbf{2}$ & II & 35 & $70 \%$ \\
\hline
\end{tabular}

Dari hasil pengamatan berkaitan dengan hasil belajar peserta didik pada setiap siklus terjadi peningkatan. Jika dibandingkan dengan siklus I, pada siklus II nilai rata-rata evaluasi meningkat dari 70,54 menjadi 84,66. Persentase ketuntasan, jika dibandingkan

dengan siklus I, pada siklus II persentase ketuntasan meningkat dari $57 \% \%$ menjadi $77 \%$. Rekapitulasi nilai rata-rata dan persentase ketuntasan nilai evaluasi untuk setiap siklus dapat dilihat pada tabel dan grafik berikut ini.

Tabel 7

Rekapitulasi Nilai Rata-rata dan Persentase Ketuntasan Hasil Belajar.

\begin{tabular}{|c|c|c|c|c|c|}
\hline No & Siklus & $\begin{array}{c}\text { Jumlah } \\
\text { Peserta } \\
\text { didik }\end{array}$ & $\begin{array}{c}\text { Jumlah } \\
\text { Nilai }\end{array}$ & $\begin{array}{l}\text { Nilai Rata- } \\
\text { rata }\end{array}$ & Persentase Ketuntasan \\
\hline 1 & I & 35 & 2469 & $\mathbf{7 0 , 5 4}$ & $57 \%$ \\
\hline 2 & II & 35 & 2963 & 84,66 & $77 \%$ \\
\hline & $\begin{array}{l}\text { Berdas } \\
\text { ar } 1, \mathrm{G} \\
\text { lapat di } \\
\text { ir pesert }\end{array}$ & $\begin{array}{l}\text { Tabel } \\
2 \text { dan } \\
\text { lkan bah } \\
\text { k kelas X }\end{array}$ & $\begin{array}{l}\text { oel } 7, \\
\text { r } 3 \text { di } \\
\text { tivitas } \\
\text { SMA }\end{array}$ & \multicolumn{2}{|c|}{$\begin{array}{l}\text { peningkatan yang signifikan pada siklus } \\
\text { II dan telah mencapai indikato } \\
\text { ketercapaian aktivitas belajar peserta } \\
\text { didik yang telah ditetapkan yaitu } \geq 70 \% \\
\text { Sedangkan hasil belajar peserta didik }\end{array}$} \\
\hline
\end{tabular}


juga mengalami peningkatan yang signifikan pada siklus II dan telah mencapai indikator ketercapaian hasil belajar yang ditetapkan $\geq 75 \%$ yaitu $77 \%$.

\section{KESIMPULAN DAN SARAN Kesimpulan}

Berdasarkan hasil analisis data pada bab IV dapat disimpulkan bahwa penerapan model pembelajaran kooperatif tipe Student Team Achievement Division berbantuan LKPD dapat meningkatkan aktivitas dan hasil belajar pada materi reaksi redoks di kelas X IPA-2 SMA Negeri 6 Pontianak, maka dapatdisimpulkan sebagai berikut :

1. Terjadi peningkatkan aktivitas belajarpeserta didik setelah melakukan kegiatan belajar dengan menerapkan model pembelajaran kooperatif tipe Student Team Achievement Division berbantuan LKPD. Pada siklus I peserta didik yang aktif sebesar $69 \%$ dari 35 peserta didik, pada siklus II peserta didik yang aktif sebanyak $89 \%$ dari 35 peserta didik.

2. Terjadi peningkatkan hasil belajar peserta didik setelah melakukan kegiatan belajar dengan menerapkan model pembelajaran kooperatif tipeStudent Team Achievement Division berbantuan LKPD. Pada siklus I peserta didik yang mencapai ketuntasan belajar sebanyak 15 peserta didik (43\%) dari 35 peserta didik, pada siklus II peserta didik yang mencapai ketuntasan belajar sebanyak 27 peserta didik $(77,14 \%)$ dari 35.

3. Penerapan model pembelajaran kooperatif tipe Student Team Achievement Division berbantuan LKPD pada materi reaksi redoks dapat menyenangkan semua peserta didik, meningkatkan kerjasama antar peserta didik, membantu memecahkan kesulitan belajar peserta didik, meningkatkan kepercayaan diri peserta didik dalam memecahkan masalah kimia, dan dapat meningkatkan keberanian peserta didik untuk mempresentasikan jawaban dihadapan teman-teman di depan kelas.

\section{Saran}

Beberapa saran berdasarkan temuan pada pelaksanaan penelitian perbaikan pembelajaran ini adalah :

a. Diperlukan waktu yang cukup untuk mempresentasikan hasil diskusi peserta didik sehingga semua pertanyaan dan tanggapan hasil presentasi dapat dilayani dan dibahas. Jadi alokasi waktu harus dirancang sebaik-baiknya sehingga dalam pelaksanaannya sesuai dengan waktu yang telah dialokasikan dalam RPP.

b. Model pembelajaran kooperatif tipe Student Team Achievement Division berbantuan LKPD dapat menjadi salah satu alternatif model pembelajaran dalam mengajarkan materi reaksi redoks.

c. Diperlukan dukungan dari pimpinan sekolah dan kerjasama antar guru sehingga banyak guru di sekolah melakukan penelitian tindakan kelas.

d. Dapat menerapkan model pembelajaran kooperatif tipe Student Team Achievement Divisionuntuk melakukan penelitian tindakan kelas pada materi berbeda dan mata pelajaran berbeda untuk memperkuat bukti hasil penelitian ini.

\section{DAFTAR RUJUKAN}

Anshory Irfan dan Achmad Hiskia. (2003). Kimia 3 untuk SMA Kelas 3. Jakarta, Penerbit Erlangga.

Arikunto, S. (2007). Prosedur Penelitian Suatu Pendekatan Praktik. Jakarta, PT. Rineka Cipta.

Budimansyah Dasim, Suparlan dan Meirawan Danny, (2010). Pembelajaran Aktif, Kreatif, Efektif, dan Menyenangkan. Bandung, PT Genesindo.

Fathurrohim, Pupuh dan Sobry Sutikno, M. (2010). Strategi Belajar Mengajar melaluiPenanaman Konsep Umum dan Konsep Islam. Bandung, PT Refika Aditama.

Hermawan, Hendy. (2006). Model-model Pembelajaran Inovatif. Bandung, CV Citra Praya. 
Liliasari. (1995). Kimia 3 untuk Sekolah Menengah Umum Kelas 3. Jakarta, Perum Balai Pustaka.

Mulyasa, E. (2009). Praktik Penelitian Tindakan Kelas. Bandung, PT RemajaRosdakarya.

Riyanto, Yatim. (2009). Paradigma Baru Pembelajaran. Jakarta, Kharisma Putra Utama.

Sardiman, A. M. (2008). Interaksi dan Motivasi Belajar Mengajar. Jakarta, PT. Raja Grafindo Perkasa.
Sujana, Atep. (2006). Sains Kimia 3 untuk SMA/MA Kelas XII IPA. Jakarta, PT. Galaxy Puspa Mega.

Suparno, Paul. (2008). Riset Tindakan untuk Pendidik. Jakarta, PT Grasindo.

Suprijono, Agus. (2013). Cooperatif Learning Teori dan Aplikasi PAIKEM. Yogyakarta, Pustaka Pelajar.

Sutresna, Nana. (2007). Cerdas Belajar Kimia untuk Kelas XII SMA/MA Program IPA. Bandung, Grafindo Media Pratama. 